\title{
Maxime Prévost, Écrire la voyance. Présence de Dante Alighieri dans «Les Proscrits» de Balzac
}

\section{Marco Stupazzoni}

\section{(2) OpenEdition}

\section{Journals}

Edizione digitale

URL: http://journals.openedition.org/studifrancesi/8669

DOI: $10.4000 /$ studifrancesi.8669

ISSN: 2421-5856

Editore

Rosenberg \& Sellier

\section{Edizione cartacea}

Data di pubblicazione: 1 décembre 2008

Paginazione: 688

ISSN: 0039-2944

\section{Notizia bibliografica digitale}

Marco Stupazzoni, «Maxime Prévost, Écrire la voyance. Présence de Dante Alighieri dans «Les Proscrits» de Balzac», Studi Francesi [Online], 156 (LII | III) | 2008, online dal 30 novembre 2015, consultato il 09 janvier 2021. URL: http://journals.openedition.org/studifrancesi/8669 ; DOI: https://doi.org/10.4000/ studifrancesi.8669

Questo documento è stato generato automaticamente il 9 janvier 2021.

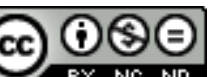

Studi Francesi è distribuita con Licenza Creative Commons Attribuzione - Non commerciale - Non opere derivate 4.0 Internazionale. 


\title{
Maxime Prévost, Écrire la voyance. Présence de Dante Alighieri dans «Les Proscrits» de Balzac
}

\author{
Marco Stupazzoni
}

\section{NOTIZIA}

MAXIME PRÉVOST, Écrire la voyance. Présence de Dante Alighieri dans «Les Proscrits» de Balzac, in «Études littéraires», printemps 2006, pp. 87-97.

1 L'opera di Dante rappresenta un punto di riferimento essenziale nella costituzione dell'immaginario medievale proprio degli scrittori romantici francesi. La trasfigurazione letteraria del poeta italiano nei Proscrits di Balzac consente di valutare l'immagine ed il ruolo attribuiti dallo scrittore francese all'autore della Divina Commedia: «il ressort de ce portrait - osserva l'autore - une ontologie implicite de l'activité littéraire: le poète (ou le romancier, c'est tout un) est un visionnaire» (p. 90), un mistico «dont les visions peuvent être imparfaites mais dévoilent nécessairement une facette de la vérité divine» (p. 91). 